\title{
ACROMEGALY COMBINED WITH GIGANTISM ASSOCIATED WITH THE AIP-GENE MUTATION: A CLINICAL CASE ${ }^{*}$
}

\author{
Nikolaiev R. ${ }^{1}$, Rostomyan L. ${ }^{2}$, Beckers A. ${ }^{2}$, Tsymbaliuk V. ${ }^{4}$, Khyzhnyak O..,3, \\ Guk M. ${ }^{4}$, Mykytyuk M. ${ }^{1,3}$, Karachentsev Iu. ${ }^{1,3}$, Sanina Y. ${ }^{1}$ \\ ${ }^{1}$ V. Danilevsky Institute for Endocrine Pathology Problems, the National Academy \\ of Medical Sciences, Kharkiv, Ukraine; \\ ${ }^{2}$ Centre Hospitalier Universitaire de Liege, Belgium, Centre de Genetique; \\ ${ }^{3}$ Kharkiv Medical Academy of Postgraduate Educations, Kharkiv, Ukraine; \\ ${ }^{4}$ Romonadov Neurosurgery Institute, the National Academy of Medical Sciences, Kyiv, Ukraine \\ oksana210562@gmail.com
}

Acromegaly is a systemic, chronic, and slowly developing disease, resulting from the excess of the growth hormone (GH) and insulin-like growth factor 1 (IGF-1) in persons with the complete physiological growth. It is characterized by pathological disproportional periosteum growth of bones, cartilages, soft tissues, internal organs, as well as disorders in the morphofunctional state of the cardiovascular and pulmonary systems, peripheral endocrine glands and various types of metabolism [1].

Acromegaly is observed most often between the ages of 20 and 40 , but sometimes it develops in persons over 50 years of age or in adolescents [2]. If the disease occurs in childhood or adolescence, when the epiphysis is not yet ossified, there is an excess in the proportional growth of the skeletal bones in length, which leads to a significant increase in the linear growth of the subject. This clinical syndrome is called gigantism. If patients with the syndrome do not receive timely and adequate treatment, they demonstrate all the typical symptoms of acromegaly in addition to gigantism after the pubertal period [3].

Pituitary gigantism is an extremely rare disorder: the incidence of pituitary tumors in children is approximately 0.1 in one million, and only about 1 to $10 \%$ of the pituitary tumors secrete the GH [4-5] in childhood. Gigantism should be suspected if the patient's height is 3 standard deviations above the normal average height or 2 standard deviations above the corrected height of parents [1]. Tumors that secrete both the GH and prolactin (PRL), termed mammosomatotroph, may

* The research was carried out as part of investigation work at the V. Danilevsky Institute for Endocrine Pathology Problems, the National Academy of Medical Sciences.

Institution, which financed the research National Academy of Medical Sciences.

The authors assume responsibility for the published work.

The authors guarantee absence of competing interests and their own financial interest when carrying out the research and writing the article.

The manuscript was received by the editorial staff 11.01.2021. 
occur, as these cells have a shared embryonic origin. When pituitary gigantism is suspected, the clinician should consider the presence of disorders, known to be associated with the GH-secreting pituitary tumors, including the McCune Albright syndrome (MAS) [6], Carney complex (CNC), multiple endocrine neoplasia, types 1 and 4 (MEN 1, MEN 4) [7], Familial isolated pituitary adenoma (FIPA), the paraganglioma, pheochromocytoma and pituitary adenoma association (PAA) due to succinate dehydrogenase defects, and X-linked acrogigantism (X-LAG) [8]. The molecular genetics of the
$A I P$-associated FIPA, MAS, CNC, and MEN 1 has been extensively studied and reviewed, especially in children and young adults [9-14].

The GH-secreting adenomas seem to be more invasive and aggressive in childhood than in adulthood [15]. Surgery has traditionally been the first line of treatment, with radiation reserved for cases that are not surgically curable [16]. Medical therapy has taken on a more important role in the management of patients with the GH excess with the development of somatostatin analogues and dopamine agonists.

\section{SUBJECT AND METHODS}

Diagnosis of acromegaly is based on the Consensus Statement (2018) [1]. Chemiluminescence has been used to detect the levels of serum GH (ng/ml), insulin-like growth factor-I (IGF-I), prolactin (PRL), thyroid-stimulating hormone (TSH), luteinizing hormone (LH), follicle-stimulating hormone (FSH), free thyroxine (fT4) using the Biomerica Immunoassay System (USA).

The national age-adjusted normal ranges of IGF-I levels are used in interpreting the results. The reference for the IGF-I (min-max) at the age of $15-16$ years is $191-496 \mathrm{ng} / \mathrm{ml}$, at the age of $17-19$ years $-190-429 \mathrm{ng} / \mathrm{ml}$, and at the age of $20-22$ years $-117-329 \mathrm{ng} / \mathrm{ml}$.

A pre- and post treatment magnetic resonance imaging (MRI) was carried out as megavoltage irradiation using $1.5 \mathrm{~T}$ linear scan Siemens MRI machine (Magnetom; Siemens AG, Munich, Germany). Informed consent to participate in the study has been obtained from the patient and his parents.

Genetic analysis has been performed in the Centre Hospitalier Universitaire de Liege, Centre de Genetique: the AIP gene partial analysis (Familial Isolated Pituitary Adenomas) by Sequencing of exons 1-6 of the AIP gene MLPA (Multiplex Lagation-dependent Probe Amplification, P244-C1) involving exons 1-6 of the AIP-gene.

Case report. A 18-year-old boy was admitted to our clinic after neurosurgery treatment in Romodanov Institute of Neurosurgery, the NAMS of Ukraine. His height was $203.5 \mathrm{~cm}$ (+3.7 SDS), body weight $97.3 \mathrm{~kg}$ (+5.5 SDS), and his feet length was $36.5 \mathrm{~cm}$ (EU size 53).
Acceleration of his growth velocity started from the age of $14 \mathrm{yrs}$. The patient had enlarged hands and feet and an increased thickness of the skin, but only discreet facial features with prognathic mandibles. His body proportions were abnormal (Fig. 1), he complained of headaches, excessive sweating, arthralgia, muscle pains and visual problems. Pubertal development was in agreement with the Tanner stage 2. Bone age corresponded to 13 years (Greulich-Pyle). Epiphyseal growth zones were open. The patient's height at the age of 22 was $209.3 \mathrm{~cm}$.

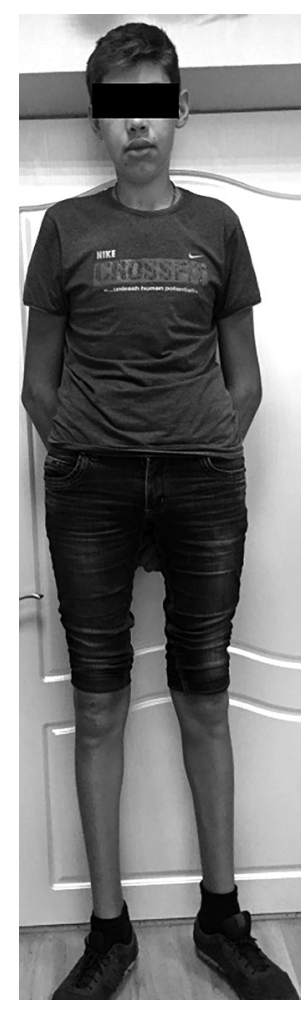

Fig. 1. 22-yr old patient S.V. with gigantism and acromegaly (height $209.3 \mathrm{~cm}$ ) 


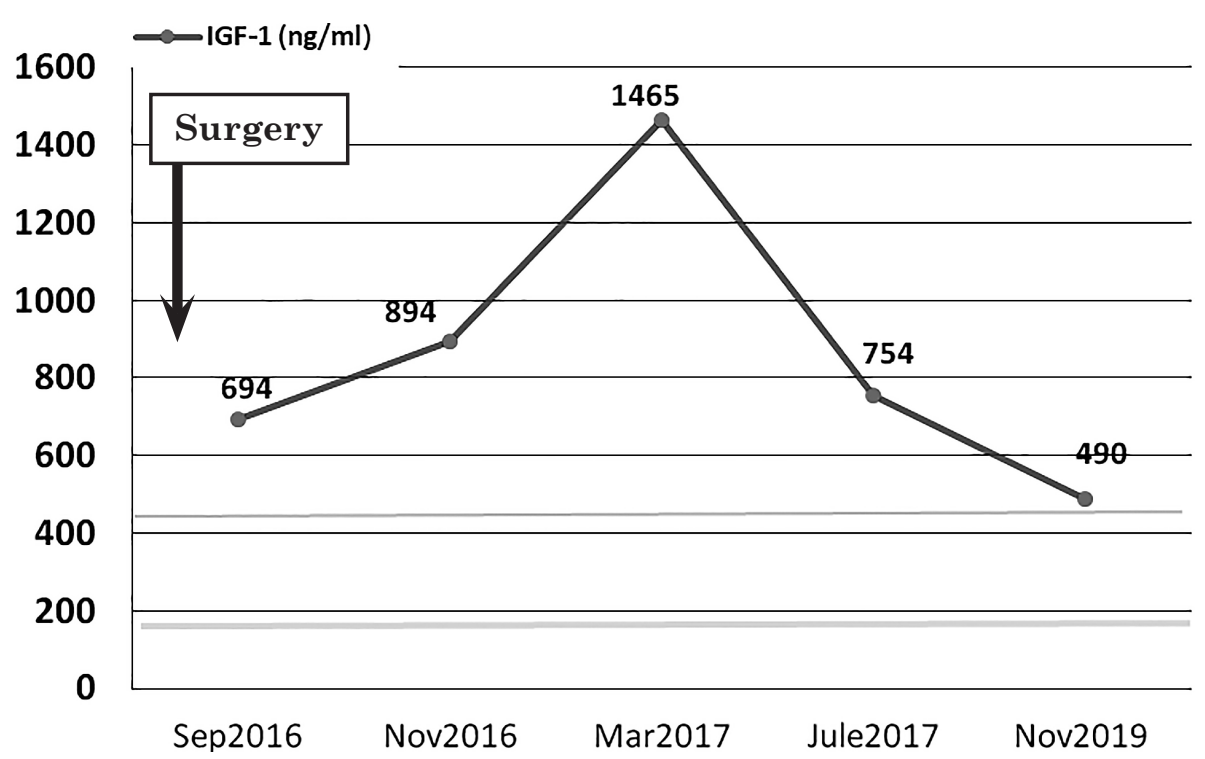

Fig. 2a. Serum IGF-I $(\mathrm{ng} / \mathrm{ml})$ levels in the patient during observation

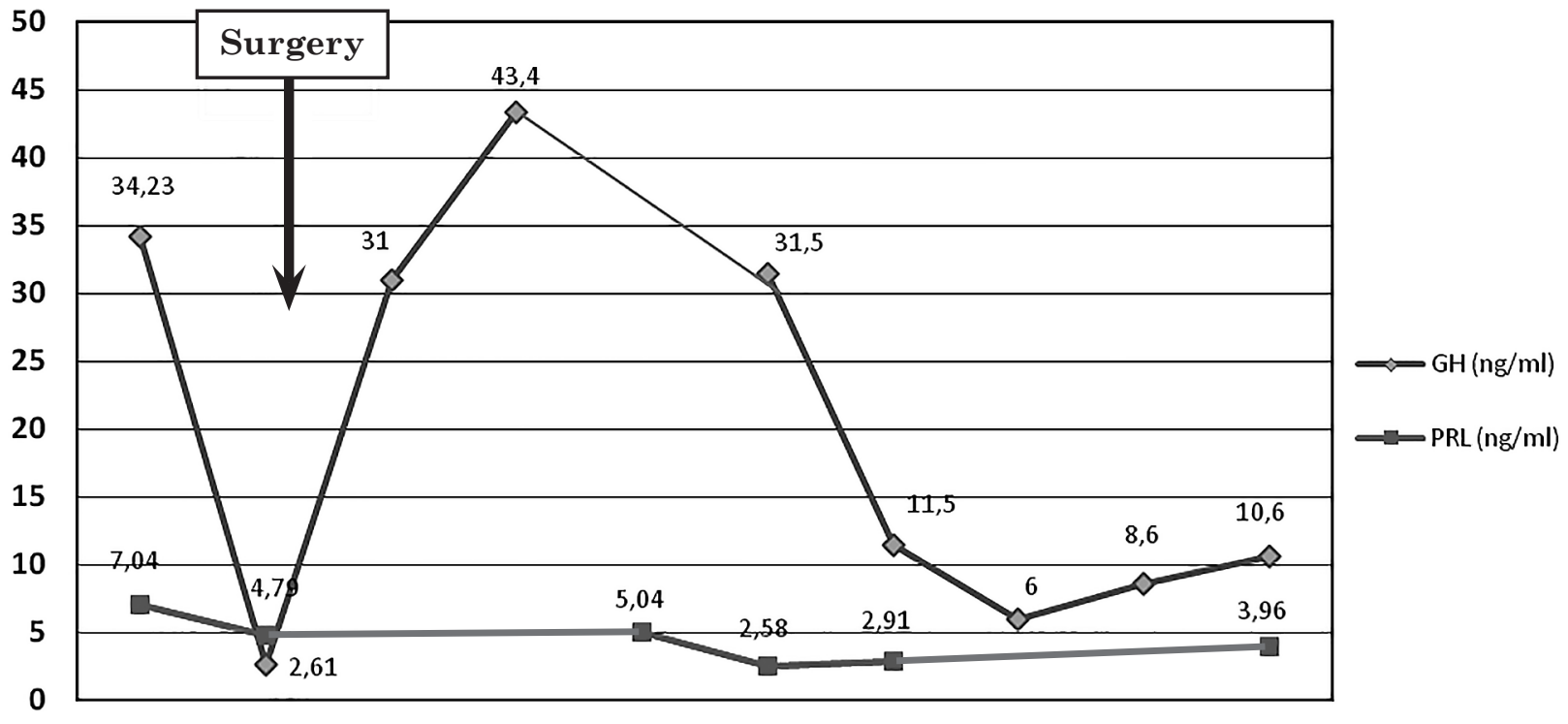

sep.16 oct.16 nov.16 mar.17 apr.17 jul.17 nov.17 mar.18 jul.18 nov.19

Fig.2b. Serum GH $(\mathrm{ng} / \mathrm{ml})$ and PRL $(\mathrm{ng} / \mathrm{ml})$ levels in the patient during observation

Anamnesis morbi, anamnesis vitae. The patient was born from the first normal pregnancy, first normal delivery, gestation age 40 weeks, birth weight $2800 \mathrm{~g}$, and birth length $50 \mathrm{~cm}$. Closed head injury took place at the age of 8 (was hospitalized; no data). Accelerated growth has been recorded since the age of 12 years. At the age of 14 yrs the patient had undergone surgery for juvenile aseptic episiolysis of the left hip joint.

Breast osteochondrosis, left-sided scoliosis (1 degree), an expressed breast kyphosis, as well as vertebrogenous thoracolgia and myofascial pain syndrome have been observed since the age of 16 . Bone age has not been determined at that time.

Family history without registration of tall stature in parents (father, $178 \mathrm{~cm}$; mother, 168 $\mathrm{cm}$ ) or any pituitary tumors and endocrine diseases.

The first endocrinological examination has been carried out at the age of 16 (19.09.2016). MRI of the brain has revealed a giant pituitary adenoma $(37 \times 36 \times 28 \mathrm{~mm})$ with suprasellar extension together with impingement on the optic chiasm and invasion of the cavernous sinus, compromising hypothalamus, anterior third ventricle and brain stems (Fig. 3a). 

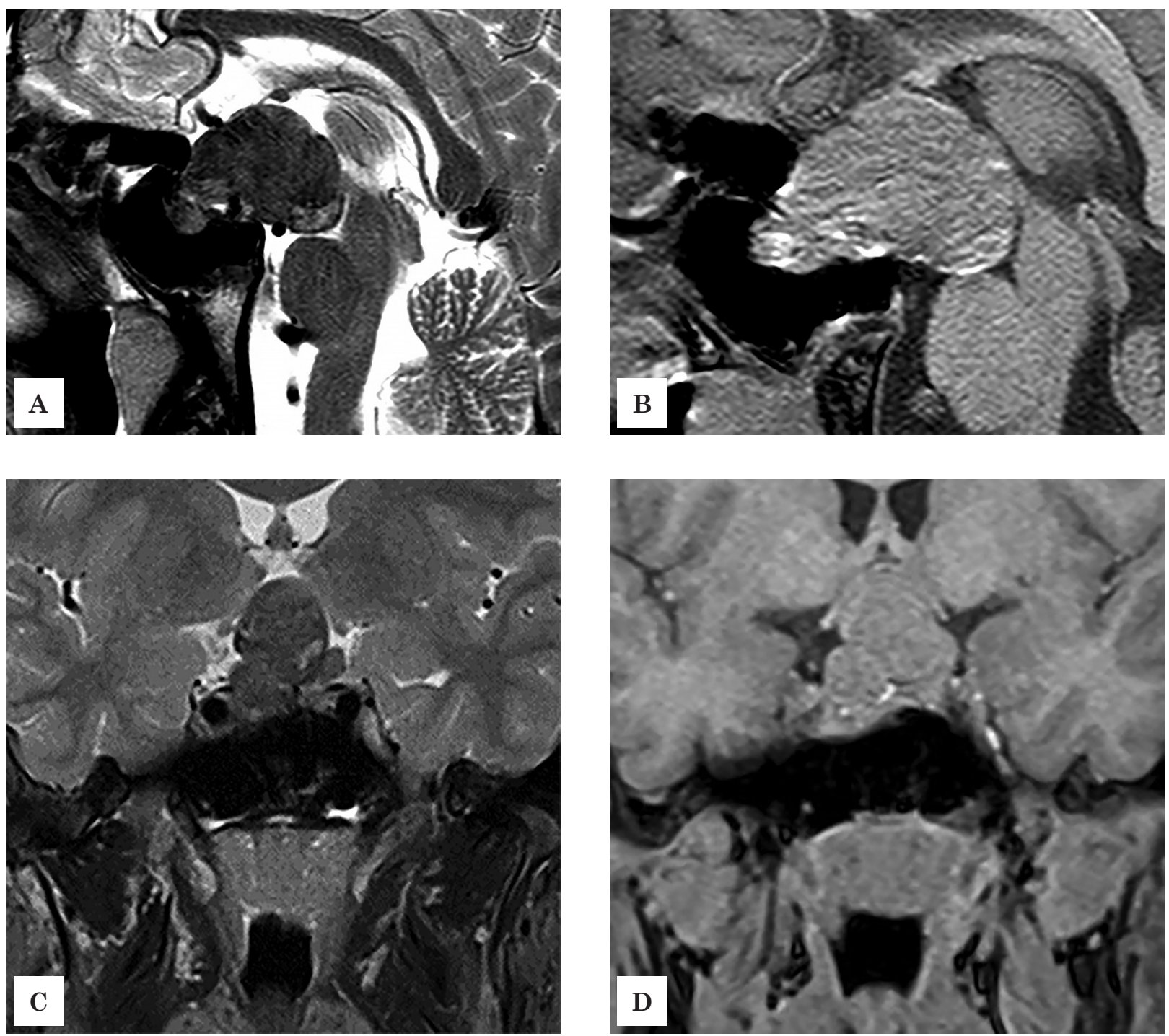

Fig. 3a. Preoperative unenhanced sagittal and coronal $T 1(B, D)$,

T2-weighted $(A, C) M R I$ sequences of the sellar region demonstrate invasive pituitary macroadenoma, with extremely low intensity on T2:

A, B - invasion of hypothalamic and ventricle III region.

$C$, $D$ - optic chiasm compression and invasion of both cavernous sinuses

Ophthalmologic examination has registered visual impairment with bitemporal field defect and optic atrophy mostly on the left eye.

The GH hypersecretion has been diagnosed together with very high levels of serum GH without suppression during OGTT (nadir serum GH, $316 \mathrm{ng} / \mathrm{ml}$ ), and a highly increased concentration of serum IGF-I $694 \mathrm{ng} / \mathrm{ml}$ (normal range for the age is $190-496 \mathrm{ng} / \mathrm{ml}$ ). Serum PRL $9.27 \mathrm{ng} / \mathrm{ml}$ (normal range $<22 \mathrm{ng} / \mathrm{ml}$ ) and TSH $0.7 \mathrm{mMU} / \mathrm{l}$ levels were in the norm (normal range $0.4-3.6 \mathrm{mMU} / \mathrm{l}$ ); a decreased cortisol level $82 \mathrm{nmol} / \mathrm{l}$ (normal range for the age is 176.0-579.4 nmol/l) (Fig. $2 a$ and $2 b$ ).
The patient underwent the transsphenoidal endoscopic surgery in Romodanov Institute of Neurosurgery, Kyiv, Ukraine, on 26.09.2016. Due to the surgical report, the tumor has turned out to be exceptionally fibrous and solid, adherent to the optical nerves and chiasm, as well as to the ventricle III bottom, where tumor remnants could not be removed without serious risks. Removal volume was described in the record as «Subtotal». Postoperative period was uncomplicated, with visual improvement, but the right temporal field defect has been registered postoperatively.

The pituitary MRI scan, performed 6 months after surgery, showed pituitary adenoma of 
a significantly reduced size: in fact, residual tumor has been determined in the suprasellar region only, mainly to the left of the middle line, with a slight chiasm compression and the ventricle III bottom involvement. Median size was $19 \times 15 \times 20 \mathrm{~mm}$, with moderate intensity of the MR-signal on T1-Wi, heterogeneously hypo-intensive on T2-Wi, (Fig. 3b).

Histological tests (Fig. 4, 1-3) have shown a pituitary adenoma with an extensive mixed B- and T-cell inflammatory response but no signs of necrosis. The immunohistochemical staining showed adenoid cells to be positive for the GH, negative for prolactin and with a slight reaction for a-subunit.

The results of the genetic analysis: genetic screening for MEN1 gene mutation was negative and no clinical symptoms, suggesting McCune-Albrights syndrome, have been demonstrated.

Heterozygous missense variant c.714C $>\mathrm{G}$ (p.Cys238Trp) has been found in the AIP-gene. This analysis of the AIP-gene is compatible with a genetic predisposition to the pituitary adenomas. The descendant of this patient has a $50 \%$ chance to inherit this variant.
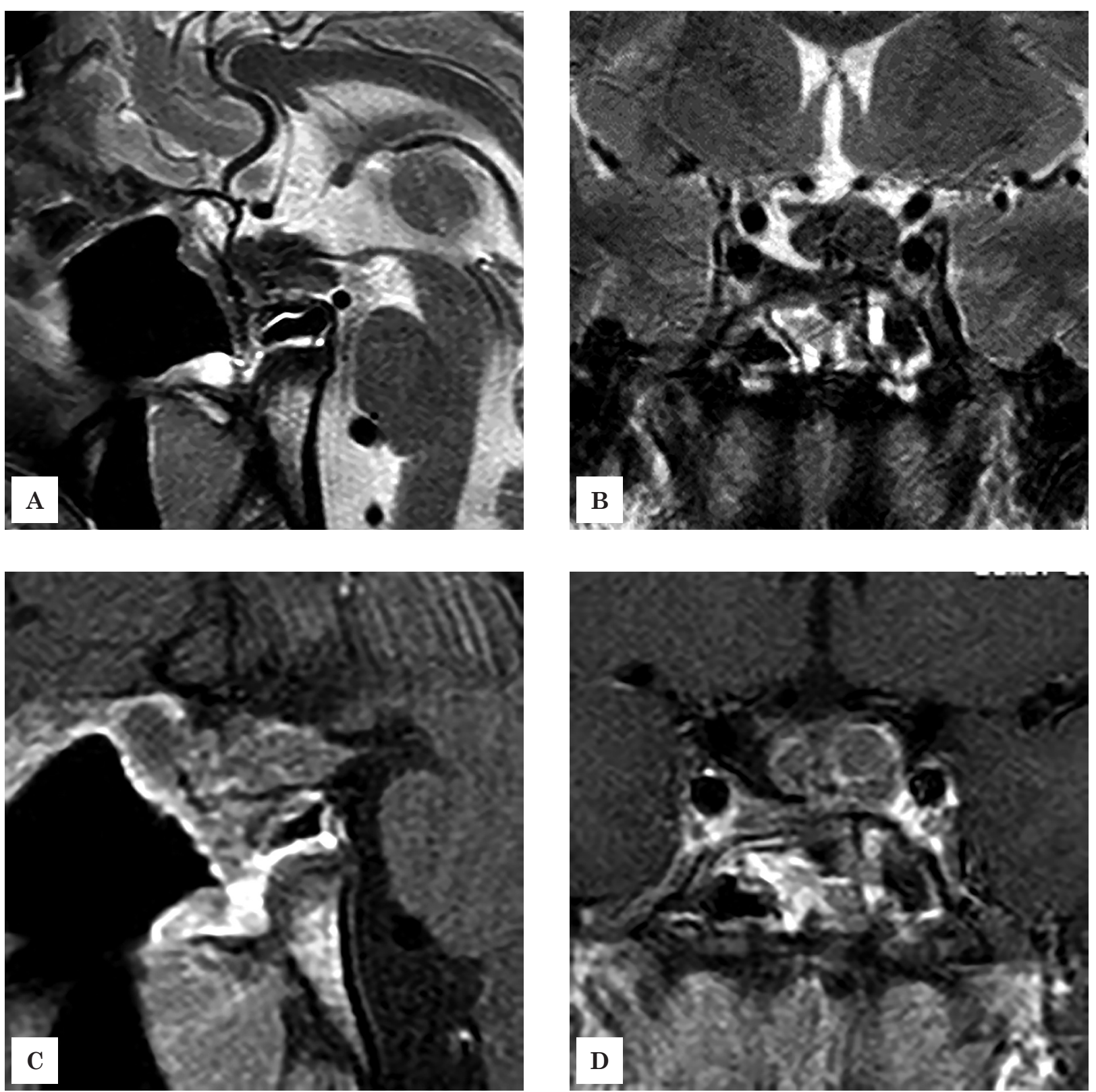

Fig. 3b. Postoperative sagittal and coronal MRI sequences of the sellar region demonstrate invasive residual tumor mass tightly attached to the ventricle III bottom: $A, B$ - non-enhanced MRI. C, D-contrast-enhanced MRI 


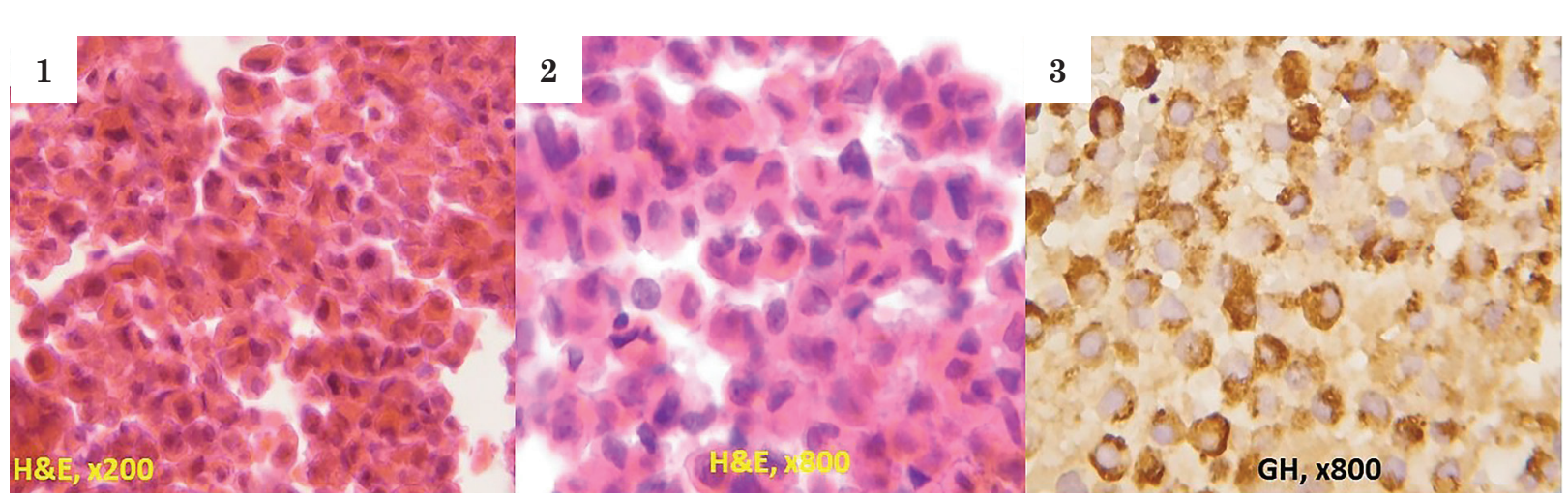

Fig. 4. 1 - General histostructure of the tumor: eosinophilic adenocytes with cellular and nuclear polymorphism. Hematoxylin staining with eosin, magnification 200x.

2 - Hematoxylin staining with eosin, magnification 800x. High mitotic activity.

3 - GH-immunostaining, hematoxylin addition, magnification 800x,

positive immunostaing for the growth hormone in most adenocytes.

(Densely granulated GH-secreting pituitary adenoma).

Cytoplasmic and transmembrane expression of somatotropes is present in $90 \%$ of cells.

Serum hormonal levels in the patient during observation

Table

\begin{tabular}{|c|c|c|c|c|c|c|c|c|}
\hline Date & $\begin{array}{l}\text { Patient's } \\
\text { age }\end{array}$ & $\begin{array}{c}\text { GH * } \\
\text { (ng/ml) }\end{array}$ & $\begin{array}{l}\text { PRL * } \\
\text { (ng/ml) }\end{array}$ & $\begin{array}{l}\text { TSH * } \\
(\mathrm{mMU} / \mathrm{l})\end{array}$ & $\begin{array}{l}\text { IGF-1 * } \\
(\mathrm{ng} / \mathrm{ml})\end{array}$ & $\begin{array}{l}\text { Cortisol } \\
\text { (blood) } \\
(\text { nmol/l) }\end{array}$ & $\begin{array}{c}\text { fT4 }{ }^{*} \\
(\mathrm{pmol} / \mathrm{l})\end{array}$ & $\begin{array}{l}\text { Testoste- } \\
\text { rone * } \\
\text { (ng/ml) }\end{array}$ \\
\hline \multicolumn{9}{|c|}{ Before surgery } \\
\hline 13.09 .16 & 18 & $316 \uparrow \uparrow \uparrow$ & 9.27 & $0.7 \downarrow$ & $694 \uparrow \uparrow$ & $82.0 \downarrow \downarrow$ & 8.9 & 3.7 \\
\hline \multicolumn{9}{|c|}{ After surgery } \\
\hline 03.10 .16 & & $35.1 \uparrow \uparrow$ & 4.79 & $0.5 \downarrow$ & $894,8 \uparrow \uparrow$ & $66.0 \downarrow \downarrow$ & & $<0.5 \downarrow \downarrow$ \\
\hline 03.03 .17 & & $43.4 \uparrow \uparrow$ & 5.04 & $0.35 \downarrow$ & $1465.0 \uparrow \uparrow \uparrow$ & $41.1 \downarrow \downarrow$ & 15.5 & $<0.5 \downarrow \downarrow$ \\
\hline 28.07.17 & 19 & $31.5 \uparrow \uparrow$ & 2.58 & $0.4 \downarrow$ & $754.7 \uparrow \uparrow$ & $8.21 \downarrow \downarrow$ & 20.8 & $1.2 \downarrow \downarrow$ \\
\hline 17.11.17 & & $11.5 \uparrow$ & 2.91 & & & NA & & \\
\hline 16.03 .18 & 20 & $6.0 \uparrow$ & & $<0.01 \downarrow \downarrow$ & $586.0 \uparrow$ & NA & 12.5 & $<0.025 \downarrow \downarrow$ \\
\hline 18.01.19 & 21 & $10.6 \uparrow$ & 3.96 & $0.02 \downarrow$ & $490.7 \uparrow$ & $26.18 \downarrow \downarrow$ & 13.5 & 2.94 \\
\hline
\end{tabular}

Note:

normal ranges: IGF-1 190.0-429.0 ng/ml for 16-18 yrs; $117.0-323.0 \mathrm{ng} / \mathrm{ml}$ for $19-22 \mathrm{yrs}$;

the levels of $\mathrm{GH}<1.0 \mathrm{ng} / \mathrm{ml}$; PRL < $20.0 \mathrm{ng} / \mathrm{ml}$; cortisol 176.0-579.4 nmol/l; TSH - 0.4-3.6 mMU/l; fT4 9.0-21.0 pmol/1; testosterone $-2.49-8.36 \mathrm{ng} / \mathrm{ml}$.

Unfortunately, no one of the endocrinologists had possibility to monitor the patient for 6 month after surgery, so our patient did not receive any treatment in this period. Postoperatively, medical treatment with subcutaneous injections of a long-acting somatostatin analogue Lanreotide Autogel (Somatulin Autogel, Ipsen Pharma AG) at a dose of $120 \mathrm{mg}$ was given every 4 weeks for 2 months and every 56 days subsequently.

However, serum GH and IFG-1 values were abnormal all the time both after surgery and in the course of the treatment (Fig 2a; 2b.; Table). Secondary hypothyroidism, secondary adrenal insufficiency and secondary hypogonadism were diagnosed in the postoperative period (Tab.). Levotyroxin (100 micrograms per day) and hydrocortisone (30 mg per day) (Cortef, Pfizer Inc.) were prescribed as hormone replacement therapy.

Substitution therapy with testosterone (50 mg/day) (Androgel, Besins Manufacturing Belgium) started at the age of 19. The patient experienced no side effects of somatostatin and hormone replacement therapy. Therapy with somatostatin analogs combined with pegvisomant was recommended for the subsequent patient's treatment [25]. 


\section{DISCUSSION}

The peculiarity of this clinical case is the occurrence of a giant pituitary adenoma in childhood, most likely at the age of 12 , after a craniocerebral injury; rapid clinical manifestation with a predominant lesion of the musculoskeletal system; pathological growth and development of classical pituitary gigantism; formation of a giant pituitary adenoma for a short period of time (presumably within 3 years), resistant to the treatment with somatostatin analogues; genetic predisposition to pituitary adenomas, as evidenced by the presence of a rare mutation in the AIP-gene. This mutation is exceedingly rare in the population databases [17, 18]. A variant of the same amino acid, p.Cys238Tyr, has been described as pathogenic of loss of function for missense AIPmuts (mutations in the aryl hydrocarbon receptor interacting protein (AIP) gene (AIPmuts)) in pituitary adenomas [19].

Substantial advances have been made recently in the pathobiology of pituitary tumors. Similar to many other endocrine tumors, the role of germline and somatic mutations has been recognized over the last few years in a number of syndromic or nonsyndromic conditions with predisposition to pituitary tumors. These include the identification of some novel germline variants in patients with familial or simplex pituitary tumors and establishment of novel somatic variants, identified through next generation sequencing [12]. Advanced techniques have allowed the exploration of epigenetic mechanisms, mediated through DNA methylation, histone modifications and noncoding RNAs, such as microRNA, long noncoding RNAs and circular RNAs.

Mechanisms of the kind can influence tumor formation, growth, and invasion. While genetic and epigenetic mechanisms often disrupt similar pathways, such as cell cycle regulation, there is a little overlap in the pituitary tumors between genes, altered by germline, somatic, and epigenetic mechanisms. The interplay between these complex mechanisms driving tumorigenesis is studied best of all in the emerging multiomics studies [12]. The functional evaluation of the AIP mutations is consistent with a tumor-suppressor role for the AIP and its involvement in the familial acromegaly. The abnormal expression and subcellular localization of the AIP in sporadic pituitary adenomas indicate deranged regulation of this protein during tumorigenesis [19].

In the original study on $A I P$ mutations and pituitary tumors, the Finnish founder mutation p.Q14X and the splice site mutation IVS3 - 1G > A accounted for a significant fraction of population-based acromegaly patients, especially in the ones, diagnosed at an early age (6 of 15 aged < $35 \mathrm{yr}$ at diagnosis) [20]. Since then it has been established that young age at the onset/diagnosis is a characteristic feature of the $A I P$-related pituitary adenomas [12]. Among large heterogeneous international populations of pituitary adenoma patients, the AIP mutations tend to occur rarely (0-3.6\%) when unselected populations are studied [21-23]. FIPA, an autosomal dominant disease with low penetrance, is being increasingly recognized. FIPA families can be divided into two distinct groups, based on genetic and phenotypic features.

Patients with mutations in the AIP-gene are characterized by young-onset somatotroph or lactotroph macroadenomas, while in the other, larger group of FIPA patients with the typically adult-onset disease and more varied adenoma types, no causative gene(s) has/have been identified. Young-onset macroadenoma patients can also be identified with germline AIP mutations without an apparent family history [12]. Germline mutations or deletions in the AIP-gene cause pituitary adenomas not only in FIPA, but also in pediatric, adolescent, and young adult cases; patients with gigantism, and potentially in those with apoplexy at a young age. AIP mutation - associated pituitary adenomas are frequently large and extensive at diagnosis, they occur at a young age, and most of them are somatotropinomas that are relatively resistant to somatostatin analog treatment $[24,25]$.

The features of pediatric somatotropinomas have been described in the review of literature, 137 pediatric somatotropinoma cases have been identified and published between 1981 and 2010, and 41 cases with AIP mutations have also been registered [24]. A slight male preponderance (59\%) has been found as 
well. Median age was 9 years at the symptoms occurrence and 14 years at the disorder diagnosis. Macroadenomas accounted for $90 \%$ of the tumors; $2 / 3$ of the children had hyperprolactinemia at diagnosis. The first-line treatment was pharmacotherapy in $1 / 3$ and surgery in $2 / 3$ of the patients. Pegvisomant was used in 7 pa- tients, it produced a significant improvement in 4 of them. The male preponderance was higher in the subgroup with AIP mutations. Mutations leading to the severe protein abnormalities were more common in the pediatric group in comparison with the group of adult patients.

\section{CONCLUSION}

In conclusion, the presented clinical case describes a rare fact of the AIP- gene mutation in the p.Cys238Tyr locus, which is associated with the occurrence of a giant pituitary adenoma in childhood. Aggressive growth of the pituitary tumor, its high proliferative and hormonal activity, clinical manifestations of gigantism in combination with severe phenotypic signs of acromegaly have also been no- ticed. Resistance to the therapy with somatostatin analogs has been revealed in our case. Considering the absence of genetic predisposition to a pituitary adenoma in the patient, this case can be regarded as a sporadic pituitary adenoma variant due to the abnormal AIP-gene expression and the disturbance of regulation during tumorigenesis.

\section{REFERENCES}

1. Melmed S, Bronstein MD, Chanson PA, et al. Nat Rev Endocrinol 2018; 14(9): 552-561. doi: 10.1038/s41574018-0058-5.

2. Khyzhnyak O, Mykytyuk M, Guk M, et al. Probl Endocrin Pathol 2019; 68(2): 119-130. doi: 10.21856/jPEP.2019.2.17.

3. Rostomyan L, Daly AF, Beckers A. Ann Endocrinol (Paris) 2015; 76(6): 643-649. doi: 10.1016/j.ando.2015.10.002.

4. Pandey P, Ojha BK, Mahapatra AK. Official J Neurosurg Soc Australasia 2005; 12(2): 124-127. doi: 10.1016/j. jocn.2004.10.003.

5. Cannavo S, Venturino M, Curto L, et al. Clin Endocrinol (Oxf) 2003; 58(4): 519-527. doi: 10.1046/j.1365-2265. 2003.01748.x.

6. Akintoye SO, Chebli C, Booher S, et al. J Clin Endocrinol Metab 2002; 87(11): 5104-5112. doi: 10.1210/jc. 2001-012022.

7. Stratakis CA, Schussheim DH, Freedman SM, et al. $J$ Clin Endocrinol Metab 2000; 85(12): 4776-4780. doi: 10.1210/jcem.85.12.7064.

8. Beckers A, Lodish MB, Trivellin G, et al. Endocr Relat Cancer 2015; 22(3): 353-367. doi: 10.1530/ERC-15-0038.

9. Eugster E. Gigantism. In: De Groot LJ, B-PP, Chrousos G, et al. Endotext, South Dartmouth, 2015.

10. Hernández-Ramírez LC, Gabrovska P, Dénes J, et al. J Clin Endocrinol Metab 2015; 100(9): E1242-E1254. doi: 10.1210/jc.2015-1869.

11. Cuny T, Pertuit M, Sahnoun-Fathallah M, et al. Eur $J$ Endocrinol 2013; 168: 533-541. doi: 10.1530/EJE-12-0763.

12. Beckers A, Aaltonen LA, Daly AF, Karhu A. Endocrine Rev 2013; 34(2): 239-277. doi: 10.1210/er.2012-1013.
13. Keil MF, Stratakis C. Expert Rev Neurother 2008; 8: 563-574. doi: 10.1586/14737175.8.4.563.

14. Chahal HS, Stals K, Unterländer M, et al. New Engl J Med 2011; 364(1): 43-50. doi: 10.1056/NEJMoa1008020.

15. Abe T, Tara LA, Ludecke DK. Neurosurgery 1999; 45(1): 1-10. doi: 10.1097/00006123-199907000-00001.

16. Dyer EH, Civit T, Visot A, et al. Neurosurgery 1994; 34(2): 207-212. doi: 10.1227/00006123-199402000-00001.

17. Leontiou CA, Gueorguiev M, Quinton R, et al. J Clin Endocrinol Metab 2008; 93(6): 2390-2401. doi: 10.1210/ jc.2007-2611.

18. Igreja S, Chahal HS, King P, et al. Hum Mutat 2010; 31(8): 950-960. doi: 10.1002/humu.21292.

19. Hernández-Ramírez LC, Martucci F, Morgan RML, et al. J Clin Endocrinol Metab 2016; 101(8): 3144-3154. doi: 10.1210/jc.2016-1307.

20. Vierimaa O, Georgitsi M, Lehtonen R, et al. Science 2006; 312: 1228-1230. doi: 10.1126/science.1126100.

21. Iwata T, Yamada S, Mizusawa N, et al. Clin Endocrinol (Oxf) 2007; 66(4): 499-502. doi: 10.1111/j.1365-2265. 2007.02758.x.

22. Korbonits M, Storr H, Kumar AV. Clin Endocrinol (Oxf) 2012; 77(3): 351-356. doi: 10.1111/j.1365-2265. 2012.04445.x.

23. Personnier C, Cazabat L, Bertherat J, et al. Horm Res Paediatr 2011; 75(6): 392-402. doi: 10.1159/000327831.

24. Joshi K, Daly AF, Beckers A, Zacharin M. Horm Res Paediatr 2018; 90(3): 196-202. doi: 10.1159/000488856.

25. Daly AF, Beckers A. Endocrinol Metab Clin North Am 2015; 44(1): 19-25. doi: 10.1016/j.ecl.2014.10.002. 


\title{
ACROMEGALY COMBINED WITH GIGANTISM ASSOCIATED WITH THE AIP-GENE MUTATION: A CLINICAL CASE
}

\author{
Nikolaiev R. ${ }^{1}$, Rostomyan L. ${ }^{2}$, Beckers A. ${ }^{2}$, Tsymbaliuk V. ${ }^{4}$, Khyzhnyak O., ${ }^{1,3}$, \\ Guk M. ${ }^{4}$, Mykytyuk M. ${ }^{1,3}$, Karachentsev Iu. ${ }^{1,3}$, Sanina Y. ${ }^{1}$ \\ ${ }^{1}$ V. Danilevsky Institute for Endocrine Pathology Problems, the National Academy of Medical Sciences, Kharkiv, Ukraine; \\ ${ }^{2}$ Centre Hospitalier Universitaire de Liege, Belgium, Centre de Genetique; \\ ${ }^{3}$ Kharkiv Medical Academy of Postgraduate Educations, Kharkiv, Ukraine; \\ ${ }^{4}$ Romonadov Neurosurgery Institute, the National Academy of Medical Sciences, Kyiv, Ukraine \\ oksana210562@gmail.com
}

Pituitary gigantism is an extremely rare disorder: the incidence of pituitary tumors in children is approximately 0.1 in one million, and only about 1 to $10 \%$ of the pituitary tumors secrete the GH in childhood. Gigantism should be suspected if the patient's height is 3 standard deviations above the normal average height or 2 standard deviations above the corrected height of parents. When pituitary gigantism is suspected, the clinician should consider the presence of disorders, known to be associated with the GH-secreting pituitary tumors, including the McCune Albright syndrome (MAS), Carney complex (CNC), multiple endocrine neoplasia, types 1 and 4 (MEN 1, MEN 4), Familial isolated pituitary adenoma (FIPA), the paraganglioma, pheochromocytoma and pituitary adenoma association (PAA) due to succinate dehydrogenase defects, and X-linked acrogigantism (X-LAG). The molecular genetics of the $A I P$-associated FIPA, MAS, CNC, and MEN 1 has been extensively studied and reviewed, especially in children and young adults. The GH-secreting adenomas seem to be more invasive and aggressive in childhood than in adulthood.

Data on a rare disease - gigantism combined with phenotypic signs of acromegaly in a young patient are presented. Clinical and laboratory parameters, data of histological and genetic analysis are described. Genetic analysis performed by AIP gene by Sequencing, proved a rare mutation in the locus of exons 1-6 of the AIP gene. The presented clinical case describes a rare fact of the AIP-gene mutation in the p.Cys238Tyr locus, which is associated with the occurrence of a giant pituitary adenoma in childhood. Aggressive growths of the pituitary tumor, its high proliferative and hormonal activity, clinical manifestations of gigantism in combination with severe phenotypic signs of acromegaly have also been noticed. Resistance to the therapy with somatostatin analogs has been revealed in this case. Considering the absence of genetic predisposition to a pituitary adenoma in the patient, this case can be regarded as a sporadic pituitary adenoma variant due to the abnormal AIP-gene expression and the disturbance of regulation during tumorigenesis.

Key words: acromegaly, gigantism, pituitary adenoma, AIP-gene mutation.

\section{АКРОМЕГАЛІЯ В ПОЄДНАННІ З ГІГАНТИЗМОМ, АСОЦІЙОВАНА З МУТАЦІЄЮ АІР-ГЕНА: КЛІНІЧНИЙ ВИПАДОК}

Ніколаев P. C. ${ }^{1}$, Rostomyan L. ${ }^{2}$, Beckers A. ${ }^{2}$, Цимбалюк B. I. ${ }^{4}$, Хижняк O. O. ${ }^{1,3}$ Гук М. А. ${ }^{4}$, Микитюк М. Р. ${ }^{1,3}$, Караченцев Ю. I., ${ }^{1,3}$, Саніна Е. М. ${ }^{1}$

${ }^{1}$ ДУ «Інститут проблем ендокринної патології ім. В. Я. Данилевського НАМН України», м. Харків, Україна; ${ }^{2}$ Centre Hospitalier Universitaire de Liege, Belgium, Centre de Genetique

${ }^{3}$ Харківська медична академія післядипломної освіти МОЗ Украӥни, м. Харків, Украӥна;

${ }_{4}^{4}$ ДУ «Інститут нейрохірургї̈ іл. акад. А. П. Ромоданова НАМН України», л. Київ, Україна oksana210562@gmail.com

Гігантизм е надзвичайно рідкісним захворювання: частота пухлин гіпофіза у дітей становить приблизно 0,1 на один мільйон, і лише близько 1 до $10 \%$ пухлин гіпофріза секретують гормон росту (ГР) в дитячому віці. Слід запідозрити гігантизм, якщо зріст паціента на 3 стандартні відхилення перевищуе нормальний середній зріст або 2 стандартні відхилення вище виправленого зросту батьків. При підозрі на гігантизм гіпофіза клініцист повинен враховувати наявність розладів, які, як відомо, пов'язані з ГР-секретуючими пухлинами гіпофіза, включаючи синдром Маккейна Олбрайта (MAS), комплекс Карні (CNC), множинні ендокринні новоутворення, типи 1 і 4 (MEN 1, MEN 4), сімейна ізольована аденома гіпофіза (FIPA), парагангліома, феохромоцитома та аденома гіпофіза (PAA) через дефректи сукцинатдегідрогенази та X-зв'язаний акрогігантизм (X-LAG). Молекулярна генетика AIPасоційованих FIPA, MAS, CNC та MEN 1 була широко вивчена та оглянута, особливо у дітей та молодих людей. Аденоми, що секретують ГР, здаються більш інвазивними та агресивними в дитинстві, ніж у зрілому віці. Представлені дані про рідкісне захворювання - гігантизм в поєднанні з фенотиповими ознаками акромегалії у молодого пацієнта. Описано клініко-лабораторні параметри, дані гістологічного і генетичного аналізу. Генетичний аналіз, виконаний методом секвенування, довів рідкісну мутацію в локусі екзонів 1-6 AIP гена. Представлений клінічний випадок описуе фракт рідкісної мутації AIP гена в p.Суs238Tyr локусі, який пов'язаний з виникненням гігантської аденоми гіпофіза в дитячому віці. Захворювання характеризуеться агресивним ростом пухлини гіпофіза, ї̈ високою проліферативною і гормональною активністю, клінічними проявами гігантизму в поєднанні 3 вираженими фенотиповими ознаками акромегалії. 3 огляду на відсутність у паціента генетичної схильності до аденомі гіпофіза, даний випадок можна розглядати як спорадичний варіант аденоми гіпофріза, причиною якої є аномальна експресія АIP-гена.

К лючові слов а: акромегалія, гігантизм, аденома гіпофіза, мутація AIP-гена. 